\title{
Coke Oven Emission Exposure
}

National Cancer Institute

\section{Source}

National Cancer Institute. Coke Oven Emission Exposure. NCI Thesaurus. Code C157008.

Occupational exposure to gases and particulates produced when coal is processed in a coke oven. 